Available online at Dakwah: Jurnal Kajian Dakwah dan Kemasyarakatan http://journal.uinjkt.ac.id/index.php/dakwah

Dakwah: Jurnal Kajian Dakwah dan Kemasyarakatan, 25 (2), 2021, 134-157

\title{
Adopsi Inovasi Komunitas Gerakan Pemuda Hijrah Terhadap Dakwah Online Pemuda Hijrah Shift Media
}

\author{
Talia Tri Ananda \\ Toyota Auto2ooo PT. Astra International Tbk
}

\begin{abstract}
Communication technology has progressed a lot from time to time, including the current development of communication technology through the internet network which includes social media such as youtube. The current phenomenon is the existence of da'wah innovation through online media, one of which is the Youtube account of Pemuda Hijrah Shift Media. This research was conducted to find out how the experience of the Youth Hijrah Movement Community regarding knowledge, persuasion, decisions, implementation, and confirmation in adopting the online da'wah innovation of Pemuda Hijrah Shift Media? Why did the Hijrah Youth Movement Community adopt the online da'wah innovation of Pemuda Hijrah Shift Media? This study uses a phenomenological method and a qualitative descriptive approach. The result of the research is that the experience of the Hijrah Youth Movement Community has known the Youtube account of Pemuda Hijrah Shift Media through two communication channels. The reason for the Hijrah Youth Movement Community to adopt the innovation of online da'wah for the Pemuda Hijrah Shift Media youtube account is because the Youtube Hijrah Shift Media YouTube account is compatible and provides benefits to the Hijrah Youth Community.

Keywords: Hijrah Youth Movement Community, Pemuda Hijrah Shift Media youtube account, adoption, innovation.
\end{abstract}

Abstrak

Teknologi Komunikasi banyak mengalami kemajuan dari waktu ke waktu, termasuk saat ini perkembangan teknologi komunikasi melalui jaringan internet yang di dalamnya meliputi media sosial seperti youtube. Fenomena yang terjadi saat ini adalah adanya inovasi dakwah melalui media online yang salah satunya adalah akun youtube Pemuda Hijrah Shift Media. Penelitian ini dilakukan untuk mengetahui bagaimana pengalaman Komunitas Gerakan Pemuda Hijrah tentang 
pengetahuan, persuasi, keputusan, implementasi, serta konfirmasi dalam mengadopsi inovasi dakwah online Pemuda Hijrah Shift Media? Mengapa Komunitas Gerakan Pemuda Hijrah mengadopsi inovasi dakwah online Pemuda Hijrah Shift Media? Penelitian ini menggunakan metode fenomenologi dan pendekatan deskriptif kualitatif. Hasil penelitiannya adalah pengalaman Komunitas Gerakan Pemuda Hijrah telah mengetahui akun youtube Pemuda Hijrah Shift Media melalui dua saluran komunikasi. Alasan Komunitas Gerakan Pemuda Hijrah mengadopsi inovasi dakwah online akun youtube Pemuda Hijrah Shift Media adalah karena akun youtube Pemuda Hijrah Shift Media memiliki kesesuaian dan memberikan keuntungan kepada Komunitas Pemuda Hijrah.

Kata kunci: Komunitas Gerakan Pemuda Hïrah, akun youtube Pemuda Hijrah Shift Media, adopsi, inovasi.

Permalink/DOI: http://doi.org/10.15408/dakwah.v25i2.23234

\section{Pendahuluan}

Gerakan dakwah Islam atau gerakan keagamaan saat ini banyak didukung oleh para kaum muda yang mulai sadar dalam menyebarkan agama Islam. Salah satu Komunitas yang saat ini sangat diminati oleh para kaum muda ialah Komunitas Gerakan Pemuda Hijrah Shift di Bandung yang berdiri pada Maret 2015, yang digerakan atas pemikiran dari udztad Tengku Hanan Attaki, Lc atau yang sering disebut dengan udztad Hanan Attaki. Udztad Hanan Attaki bersama beberapa rekannya berinisiatif membuat Komunitas Gerakan Pemuda Hijrah dengan tujuan dan harapan agar dapat memberikan tempat (wadah) untuk orangorang yang berkeinginan untuk berhijrah dan lebih mendekatkan diri kepada Allah SWT dengan lebih memahami dan mendalami ilmu agama Islam.

Komunitas Gerakan Pemuda Hijrah terbentuk dengan tujuan untuk mengajak masyarakat sekitar Bandung khususnya para kaum muda untuk mau ikut meramaikan masjid serta membuat suatu kajian keIslaman yang dikemas secara kekinian, ringan tetapi bisa menarik sehingga tidak membosankan dan membuat para jamaah tertarik, nyaman dan senang. Dalam berusaha mengajak anak muda untuk datang ke kajiannya, pengurus gerakan Pemuda Hijrah pun juga akhirnya menggunakan media sosial sebagai sarana menyampaikan informasi kajian, sebab media sosial yang memanfaatkan teknologi komunikasi internet saat ini sudah menjadi bagian dari kehidupan para kaum muda, selain itu juga hampir semua kaum muda pasti menggunakan smartphone yang mengakses facebook, twitter, instagram hingga youtube. hal tersebut ialah inovasi berdakwah melalui media online.

Peranan berdakwah melalui media online (internet) menjadi sangat penting, secara khusus terdapat tiga alasan mengapa dakwah melalui media online manjadi penting, yaitu yang pertama karena muslim telah menyebar ke seluruh dunia. Di dunia, Islam sekarang merupakan agama dengan pemeluk terbanyak kedua setelah Kristen. Hal yang sama juga terjadi di Amerika, Perancis, dan Inggris. Pertumbuhan 
pemeluk Islam di negara Eropa lainnya dan Australia juga sangat pesat. Internet merupakan sarana yang mudah dan murah untuk selalu keep in touch dengan Komunitas muslim yang tersebar di segala penjuru dunia.

Kedua, Citra Islam yang buruk akibat pemberitaan satu sisi oleh banyak media barat perlu diperbaiki. Internet menawarkan kemudahan untuk menyebarkan pemikiran pemikiran yang jernih dan benar serta pesan-pesan ketuhanan keseluruh dunia. Karena dalam konteks ini, internet banyak digunakan untuk menyebarkan propaganda antiIslam atau memberikan informasi tentang Islam yang salah, maka penggunaan internet merupakan salah satu cara efektif untuk melawannya sekaligus melakukan dakwah ke komunikasi non-muslim.

Ketiga, memanfaatan internet untuk berdakwah dengan sendirinya juga menunjukan bahwa muslim juga bisa menyesuaikan diri dengan perkembangan peradaban yang ada, selama itu tidak bertentangan dengan aqidah. Di Negaranegara maju, media online ini telah memudahkan muslim dalam mengelola dakwahnya dan berkomunikasi dengan anggota jama'ah lainnya. Penguasaan teknologi ini juga dapat menghilangkan ketergantungan kita kepada pihak barat dan menjadikan muslim minimal bisa berdiri sejajar dengan orang-orang barat dan menjadi orang yang benar-benar merdeka. ${ }^{1}$

Berdakwah merupakan kewajiban setiap manusia, setiap orang dalam berbagai profesi bisa melakukan dakwah, sebab berdakwah dapat dilakukan dalam multidimensi kehidupan. Sebagaimana yang kita ketahui dakwah Islam bukan hanya dengan cara bi al-lisan (dengan ungkapan ucapan dan kata-kata), bi al- kitab (dengan tulisan atau bacaan), bi attadbir (manajemen ataupun pengorganisasian), serta bi al-hal (aksi ataupun kegiatan sosial). Seorang $d a^{\prime} i$ ataupun mubaligh yang baik tidak hanya menguasai materi dakwah tetapi juga harus memahami karakteristik serta budaya masyarakat ( $m a d$ 'u) yang menjadi sasaran dakwahnya. ${ }^{2}$

Saat ini di Indonesia dakwah tidak hanya dilakukan sebatas pemberian khutbah di Masjid ataupun di Musholla, kantor-kantor, sekolah maupun lembaga formil lainnya, tetapi seiring berkembangnya kemajuan teknologi komunikasi, penyebaran dakwah Islam sudah berkembang dengan melalui teknologi media, khususnya teknologi komunikasi dan informasi yaitu internet. Internet sudah difungsikan sebagai media berdakwah online, hal tersebut semakin memudahkan umat muslim untuk menyampaikan dakwah dan mendapatkan pengetahuan Islam.

Dengan semakin terbuka lebarnya kemudahan dalam menyampaikan dakwah melalui jaringan internet, maka saat ini banyak bermunculan inovasiinovasi gerakan berdakwah melalui media online yang salah satunya lahir dari Gerakan Pemuda Hijrah. Inovasi dari Gerakan Pemuda Hijrah dalam berdakwah melalui media online ialah suatu inovasi terbaru dalam syiar Islam, dan pastinya akan memudahkan para $d a^{\prime} i$ dalam melebarkan sayapnya, serta memudahkan para mad'u dalam mendapatkan informasi yang diinginkan. Penggunaan media online internet sebagai media dakwah merupakan kesempatan dan tantangan untuk mengembangkan dan memperluas cakrawala dakwah Islam.

Akun media sosial yang dibuat oleh pengurus gerakan Pemuda Hijrah 
ialah dikhususkan untuk berdakwah online yang diberi nama Pemuda Hijrah Shift Media. Akun Pemuda Hijrah Shift Media tersebut ialah hasil inovasi dari adanya perkembangan teknologi komunikasi yang diciptakan untuk menghadapi tantangan perubahan zaman.

Akun Pemuda Hijrah Shift Media bertujuan untuk dapat memberikan informasi bagi orang-orang yang ingin mengetahui lebih dalam lagi tentang pengetahuan Islam serta bertujuan agar orang-orang senantiasa berhijrah untuk lebih mendekatkan diri kepada Allah SWT dengan belajar dan mendalami ilmu agama Islam secara online serta agar semakin meluasnya Komunitas gerakan Pemuda Hijrah yang tersebar ke seluruh masyarakat luas bukan hanya pada masyarakat di Bandung saja, tetapi masyarakat yang berada di luar Bandung pun bisa masuk dan ikut serta dalam Komunitas gerakan Pemuda Hijrah yang berkumpul di akun media sosial Pemuda Hijrah Shift Media.

Dengan adanya inovasi berdakwah melalui media online dengan nama Pemuda Hijrah Shift Media, para individu-individu yang berkumpul di Komunitas Gerakan Pemuda Hijrah pun pastinya melakukan pengadopsian terhadap inovasi dakwah online yaitu pada akun media sosial Pemuda Hijrah Shift Media tersebut. Individu-individu yang berkumpul pada Komunitas Gerakan Pemuda Hijrah yang mengadopsi akun media sosial Pemuda Hijrah Shift Media tersebut juga pasti harus melewati beberapa proses dalam pengadopsian inovasi tersebut sehingga akhirnya akun Pemuda Hijrah Shift Media berhasil diadopsi dan individu yang telah mengadopsi (adopter) akun Pemuda Hijrah Shift Media sampai ke tahap konfirmasi, yaitu tahap terakhir dalam proses pengadopsian suatu inovasi.

Penelitian ini menggunakan metode fenomenologi. Fenomenologi pada dasarnya merupakan strategi penelitian dimana di dalamnya peneliti mengidentifikasi hakikat pengalaman manusia tentang suatu fenomena tertentu. Memahami pengalaman-pengalaman hidup manusia menjadikan fenomenologi sebagai suatu metode penelitian yang prosedur-prosedurnya mengharuskan peneliti untuk mengkaji sejumlah subjek dengan terlibat secara langsung dan relatif lama didalamnya untuk mengembangkan pola-pola serta relasi-relasi makna. ${ }^{3}$

Inti dari penelitian fenomenologi adalah ide atau gagasan mengenai 'dunia kehidupan' (life world), sebuah pemahaman bahwa realitas setiap individu itu berbeda dan bahwa tindakan setiap individu hanya bisa dipahami melalui pemahaman terhadap dunia kehidupan individu, sekaligus lewat sudut pandang mereka masing-masing. Hal tersebut merupakan tugas peneliti untuk mengakses 'pikiran akal sehat' orangorang dengan tujuan menafsirkan motifmotif, tindakan, pengalaman, serta dunia sosial dan dunia kehidupan mereka dari sudut pandang mereka. ${ }^{4}$ Fenomenologi ingin mengungkapkan apa yang menjadi realitas dan pengalaman yang dialami oleh individu. ${ }^{5}$

Tujuan utama pada penelitian fenomenologi ialah untuk mendeskripsikan pemaknaan umum atau sama dari sejumlah individu terhadap pengalaman hidup mereka terkait dengan konsep dan fenomena yang terjadi serta untuk mereduksi atau membuat potongan pengalaman individu pada fenomena menjadi deskripsi tentang esensi 
(kenyataan) atau inti sari universal (rangkuman umum).

\section{Proses Adopsi Inovasi}

Difusi dan adopsi inovasi memiliki hubungan dan keterkaitan yang sangat erat. Everett M. Rogers telah mejelaskan bahwa adopsi merupakan keputusan untuk menggunakan inovasi, yaitu gagasan, metode maupun objek yang dianggap baru oleh individu ataupun sekelompok individu. Inovasi yang digunakan tersebut bertujuan untuk mempermudah kehidupan masyarakat serta merubah kehidupan masyarakat agar menjadi lebih baik dan bermutu. Seorang individu telah melewati berbagai proses untuk mengadopsi suatu inovasi. Keberhasilan seorang individu dalam mengadopsi suatu inovasi ditandai dengan adanya perubahan pengetahuan, sikap, serta perilaku dari individu tersebut dalam menerapkan inovasi ke kehidupan sehari-hari. Hal tersebut tertulis dalam teori Everett M. Rogers dalam bukunya Diffusion of Innovation (1983) yaitu newness in an innovation need not just involve new knowledge. Someone may have known about an innovation for some time, but not yet developed a favorable un favorable attitude toward it, or have adopted or rejected it. The "newness" aspect of an innovation may be expressed in terms knowledge, persuation, an a decision to adopt. ${ }^{6}$

Sementara itu, konsep proses pengambilan keputusan dalam mengadopsi inovasi (decision process) merupakan pengenalan inovasi yang akan menambah pengetahuan individu tmengenai hal awal dari inovasi. Pengetahuan akan mendorong sikap individu untuk mendukung keberadaan inovasi dan menggunakannya di kehidupan sehari-hari. (The innovation decision process is the process trhough which an individual (or other decision making unit) passes from first knowledge of an innovation, to forming an attitude toward the innovation, to decision adopt or reject, to implementation of the new idea, and to confirmation of this decision). ${ }^{7}$

Konsep proses pengambilan keputusan (decision process) menurut Rogers diatas harus melewati beberapa proses. Adapun proses pengambilan keputusan tersebut terbagi ke dalam lima tahap, yaitu sebagai berikut: Proses pengetahuan (Knowledge); Proses persuasi (Persuation); Proses keputusan (Decision); Proses penerapan (Implementation); Proses konfirmasi (Confirmation).

Pada tahap pengetahuan (knowledge), individu telah mengetahui adanya atau hadirnya inovasi. Individu mengetahui dan memperoleh informasi tentang inovasi tersebut melalui saluran komunikasi yaitu media massa dan melalui saluran komunikasi interpersonal. Proses persuasi adalah proses dimana seorang individu membentuk sikap baik (positif) yaitu menerima dan mendukung atau membentuk sikap tidak baik (negatif) yaitu menolak dan tidak mendukung inovasi. Pada proses pesuasi, berbagai pihak memmpengaruhi individu untuk menggunakan inovasi dalam kehidupan sehari-hari. Menurut Rogers dalam tahap persuasi ini, saluran komunikasi interpersonal lebih efektif.

Proses pada tahap keputusan merupakan proses dimana individu mengambil keputusan untuk mengadopsi inovasi ataupun menolak untuk mengadopsi inovasi. Jika individu memutuskan untuk mengadopsi inovasi 
maka individu akan menggunakan inovasi dalam kehidupan sehari-hari, namun jika tidak maka individu tidak akan menggunakan inovasi dalam kehidupan sehari-hari. Tetapi masih banyak pengaruh dari faktor-faktor pendorong inovasi sehingga membuat individu dapat mengubah keputusannya dikemudian waktu. Pada tahap inilah yang menentukan apakah proses dari adopsi inovasi akan berlanjut pada tahap berikutnya atau tidak.

Proses penerapan ialah proses dimana individu telah mengambil keputusan untuk mengadopsi produk inovasi dan mengimplementasikan dalam kehidupan sehari-hari. Setelah mengunakan dan mencoba produk inovasi dalam skala kecil dan dalam jangka waktu singkat, individu akan memperoleh alasan yang semakin kuat untuk menerima (tetap menggunakan) atau menolak (berhenti menggunakan) inovasi tersebut.

setelah individu melewati keempat proses diatas, maka individu akan memperoleh sejumlah informasi dan penilaian terhadap inovasi yang telah digunakan. Pada tahap konfimasi individu akan menguatkan keputusannya untuk menolak atau menerima inovasi tersebut. Dan pada tahap ini juga, seorang individu yang menerima dan merasa puas terhadap inovasi yang diadopsi akan mengajak dan memberikan informasi baik kepada individu lain agar ikut mengadopsi inovasi, tetapi jika individu menolak dan merasa tidak puas dengan inovasi yang digunakan, maka individu juga akan mempengaruhi dan memberikan informasi buruk kepada individu lainnya agar tidak mengadopsi inovasi tersebut.

Dari berbagai definisi diatas, dapat disimpulkan bahwa inovasi adalah suatu proses memikirkan dan mengimplementasikan pemikiran tersebut, sehingga menghasilkan hal baru yang berbentuk, produk, jasa, proses bisnis, cara baru, kebijakan, dan lain sebagainya. Inovasi juga adalah sebuah karya manusia, baik sebagai individu maupun sebagai kelompok orang yang bekerjasama (organisasi).

\section{Pengertian Dakwah Online}

Kata dakwah berasal dari bahasa Arab yaitu da'wah, yaitu sebagai bentuk masdar dari kata kerja da-aa yad-uu. Kata dakwah menurut arti bahasa mempunyai beberapa arti yaitu mengharap dan berdoa kepada Allah SWT, memanggil dengan suara lantang, serta mendorong seseorang untuk memeluk sesuatu keyakinan tertentu. ${ }^{8}$ Sedangkan menurut istilah, dakwah berarti suatu aktivitas yang mendorong manusia memeluk agama Islam melalui cara yang bijaksana dengan materi ajaran Islam agar mereka mendapatkan kesejahteraan kini (dunia) dan kebahagiaan nanti (akhirat). ${ }^{9}$

Menurut Abdul Aziz dakwah berasal dari bahasa Arab yaitu da'wah yang diambil dari kata da'a, yad'u, $d a$ 'watan yang berarti seruan, panggilan, undangan dan doa. Dakwah juga bisa berarti memanggil, menyeru, menegaskan, membela sesuatu, perbuatan dan perkataan untuk menarik manusia kepada sesuatu, memohon, dan juga meminta. ${ }^{10}$

Dakwah juga suatu proses mengajak, menyeru, serta membimbing umat manusia untuk berbuat baik dan mengikuti petunjuk Allah dan RasulNya. Usaha dilakukan secara sengaja dengan perencanaan yang matang baik dilakukan oleh individu atau organisasi dengan sasaran yaitu umat perseorangan ataupun 
sekelompok orang (masyarakat) agar mereka mengetahui, mengimani, serta mengamalkan, ajaran Islam pada semua aspek kehidupan. Dakwah juga diupayakan secara bijaksana agar tercapai kehidupan yang sejahtera di dunia maupun di akhirat. ${ }^{11}$

Kemajuan teknologi informasi dan komputer telah menyebabkan perubahan yang sangat mendasar dalam tata kehidupan manusia. Teknologi komunikasi dan informasi telah mengubah pola hubungan manusia. Manusia semakin terbebaskan dari ikatan ruang dan waktu. kehadiran internet telah mendekatkan hubungan antar manusia di seluruh dunia. ${ }^{12}$ Hakekat dakwah ialah untuk mempengaruhi serta mengajak manusia untuk mengikuti dan menjalankan ideologi pengajaknya (Da'i), sedangkan Da'i sudah pasti memiliki tujuan yang hendak dicapainya. Agar proses dakwah tersebut mencapai tujuan yang efektif dan efisien, seorang Da'i harus mampu mengorganisir komponenkomponen (unsur) dakwah secara baik dan tepat. Salah satunya dengan menggunakan komponen media dakwah. ${ }^{13}$

Berhubungan dengan penggunaan media dakwah, media internet akan menjadi media dakwah yang efektif dan efisien karena jangkauan dan macammacam informasi yang mengalir begitu pesat yang akan menembus batas ruang dan waktu. ${ }^{14}$ Cakupan geografis dakwah melalui internet tidak akan terbatas dan semua pengguna internet dapat tersentuh oleh jenis dakwah melalui internet. ${ }^{15}$

Hampir semua bidang dan pekerjaan manusia apapun jenisnya dapat dicari melalui internet. Internet ialah sebagai sumber informasi yang menyebabkan semua orang selalu belajar seumur hidup, kapan dan dimanapun serta untuk keperluan apapun. ${ }^{16}$ Oleh karena itu, dalam perkembangan selanjutnya media ini menempatkan posisi yang lebih kuat dibandingkan dengan media yang sudah ada sebelumnya. ${ }^{17}$ Hal tersebut terlihat dan dibuktikan ketika perangkatperangkat komputer baik hardware maupun software terus menerus berkembang dan terus menerus disempurnakan setiap saat. Sejauh ini pula sambutan masyarakat sangat antusias. $^{18}$

Penyebaran ajaran Islam atau dakwah Islam melalui internet dapat dilakukan dalam berbagai bentuk bergantung pada kemampuan kreatifitas dan kemampuan Da'i baik secara individual ataupun kolektif. ${ }^{19}$ Begitu besarnya potensi dan efisiensi yang dimiliki oleh kecanggihan jaringan internet membuat terbentuknya jaringan dan pemanfaatan dakwah, maka saat ini dakwah dapat dilakukan dengan membuat jaringan-jaringan informasi tentang Islam atau yang sering disebut dengan cybermuslim atau cyberdakwah. ${ }^{20}$

Dengan segala kelebihan dan kekurangan yang dimiliki oleh internet ternyata internet mampu menjadi salah satu media alternatif untuk menyampaikan informasi dakwah dalam era globalisasi. Jika umat Islam tidak memanfaatkan media-media yang ada pada zaman modern yang ditandai dengan perkembangan teknologi komunikasi, maka dakwah Islam akan semakin terasing dari umat manusia dan tergulung oleh persaingan ideologi serta agamaagama besar lainnya. ${ }^{21}$

\section{Media Sosial}

Media sosial ialah sarana interaksi antara sejumlah individu melalui 
"sharing" informasi dan ide-ide melalui jaringan internet bertujuan untuk membentuk semacam Komunitas virtual. $^{22}$ Media sosial muncul sebagai bagian dari perkembangan teknologi komunikasi dan media baru yang memperbaharui media lama seperti media cetak. Perbedaan antara media sosial sebagai media baru dengan media lama ialah dalam hal kualitas, frekuensi, jangkauan, kedekatan, kegunaan, dan sifatnya yang selamanya (permanen) seperti internet.

Media sosial adalah media yang didesain atau dibuat untuk memudahkan interaksi sosial, yang bersifat interaktif. Brian Solis yaitu seorang penggagas penggunaan media sosial asal Amerika Serikat mendefinisikan media sosial sebagai demokratisasi isi serta perubahan peran publik dalam membaca serta menyebarkan informasi. ${ }^{23}$ Media sosial merupakan alat komunikasi berbasis internet yang memungkinkan setiap penggunanya berbagi pesan dalam bentuk apapun yaitu tulisan, gambar, video, serta suara kepada setiap orang di seluruh dunia yang mempunyai akses internet.

Heidi Coben mengatakan bahwa definisi media sosial terus menerus berubah dan berkembang seiring dengan berjalannya dan berkembangnya penggunaan media sosial itu sendiri. Menurut Heidi Coben media sosial merupakan salah satu bentuk platform online di mana para pengguna dapat memindahkan konten yang bersumber dari WordPress, Sharepoint, Youtube, dan Facebook. Secara singkatnya media sosial meliputi saluran user-generated content yang memandang media sosial sebagai teknologi sosial. Media sosial meliputi Youtube, Facebook, Twitter, Instagram, Line, Whatsapp, dan lain sebagainya. ${ }^{24}$

\section{Sejarah Berdirinya Gerakan Pemuda Hijrah Shift}

Gerakan Pemuda Hijrah atau yang sering disebut dengan Shift ialah salah satu gerakan dakwah yang resmi terbentuk pada tahun 2015. Gerakan pemuda hijrah didirikan oleh Ustad. Hanan Attaki bersama rekannya yaitu Fani Kisnandar atau yang biasa disapa dengan panggilan kang Inong. Sebelum gerakan pemuda hijrah terbentuk oleh Ustad Hanan Attaki dan kang Inong, Ustad Hanan Attaki sudang sering mengisi kajian di Masjid Al-Lathiif Bandung, tetapi Ustad Hanan Attaki masih menggunakan metode dakwah pada umumnya dan juga masih mengenakan pakaian gamis dan sorban serta gaya bahasa yang keras dan tegas. Hingga pada akhirnya, Ustad Hanan Attaki merasa bahwa jamaah yang hadir di kajiannya hanya jamaah itu-itu saja, dan jarang sekali kaum muda yang datang untuk menghadiri kajiannya. Kemudian, Ustad Hanan Attaki berbincang dengan beberapa rekannya yang salah satunya adalah kang Inong.

Perbincangan Ustad Hanan Attaki dengan rekan-rekannya terkait bagaimana cara mengemas dakwah tanpa harus merubah isinya tetapi menjadi lebih menarik dan lebih mudah diterima oleh kalangan pemuda. Karena memang Ustad Hanan Attaki berkeinginan tujuan dakwahnya bisa diterima di kalangan muda, maka akhirnya semua konsepnya menyesuaikan dengan gaya anak muda, dari gaya bahasa, busana, hingga tema dan materi dakwah juga disesuaikan dengan permasalan di kalangan anak muda. Akhirnya dari perbincangan dan musyawarah tersebut, terbentuklah Gerakan Pemuda Hijrah atau Shift. 
Sasaran dakwah dari Ustad Hanan attaki adalah kaum remaja yang ada di ring tiga yaitu kaum muda yang netral yang tidak mendukung kegiatan dakwah tetapi tidak memusuhi kegiatan dakwah dan ring empat yaitu kaum muda yang oposisi, yang menolak, yang tidak suka eksistensi Islam, dan mereka adalah Islamophobia. Maka dari itu, pendekatannya, produknya, bahasannya, serta penetrasinya semua untuk mereka yang berada di ring tiga dan ring empat.

Sekretariat Gerakan Pemuda Hijrah atau yang sering disebut dengan basecamp oleh Komunitas Gerakan Pemuda Hijrah bertempat di Masjid untuk menjadi sebaik-baiknya anak manusia serta untuk menumbuhkan minat anak muda agar ikut meramaikan masjid dan taklim; Mengajak sebanyakbanyaknya manusia dari kegelapan menuju jalan kebenaran; Merangkul anak muda untuk kembali ke ajaran agama Islam; Mengembalikan pandangan manusia tentang hijrah, bahwa hijrah tidak akan menghambat kehidupan apapun itu; Mengubah styreotype anak muda. Yang awalnya hijrah itu tidak keren menjadi keren; Menghadirkan kegiatan-kegiatan dakwah dan produkproduk dakwah yang diterima oleh anak muda dan menarik perhatian anak muda;

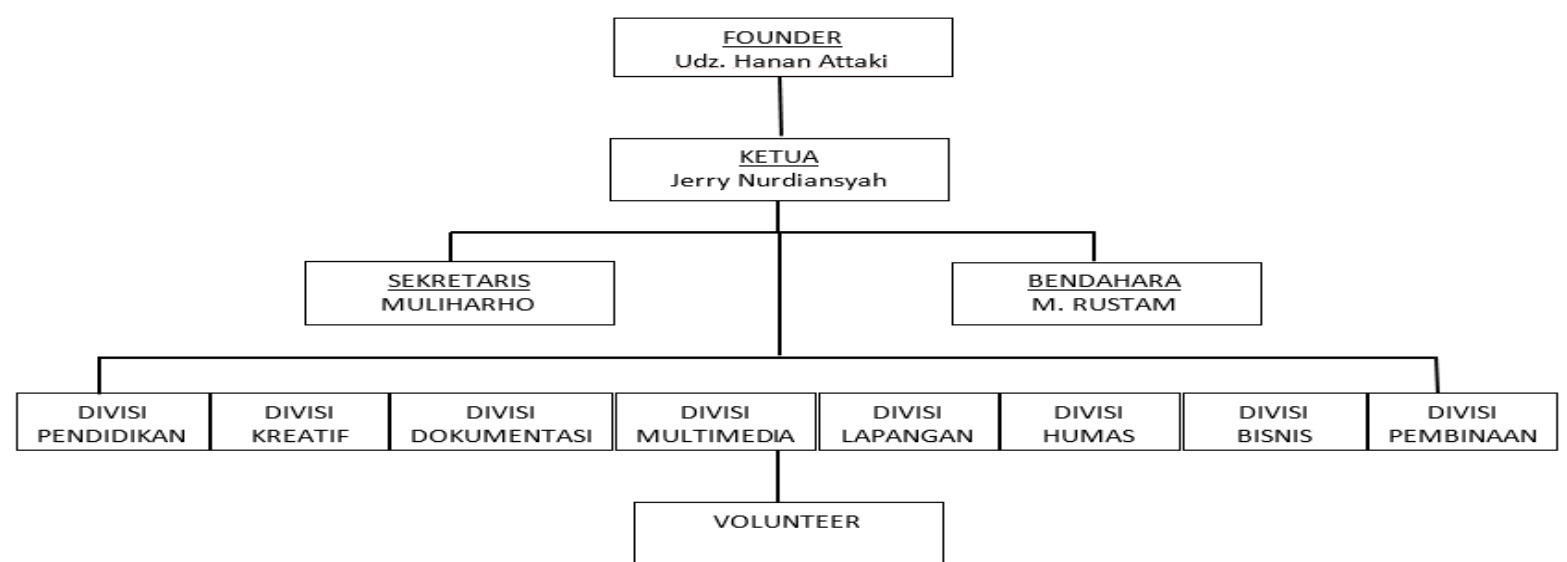

Alathiif yang berada di Jalan Saninten No. 2 Cihapit, Bandung Wetan, Kota Bandung.

Visi dari Gerakan Pemuda Hijrah adalah untuk mengisi peradaban dengan berdakwah kepada kaum muda sebagai asset masa depan bagi umat dan bangsa untuk menjadi sosok pemuda yang sesuai dengan tuntunan Islam yakni pemuda yang senantiasa dekat dengan Al-Quran, shalat tepat waktu, semangat mencari ilmu agama, serta dapat senantiasa menjadi generasi penerus dalam menyiarkan agama Islam.

Sementara Misi Gerakan Pemuda Hijrah yakni Untuk mengajak anak muda
Membuat anak muda jatuh cinta kepada agama Islam.

Motto dari Gerakan Pemuda Hijrah adalah "Banyak main, Banyak manfaat, Banyak pahala, Sedikit dosa". Motto tersebut memiliki arti dimana mengajak anak muda khususnya untuk lebih banyak bergerak dan beraktifitas yang bermanfaat dan tidak harus selalu tentang gadget. Gerakan Pemuda Hijrah juga ingin mengajak anak muda untuk kembali kepada ajaran agama khususnya ajaran agama Islam melalui kegiatan-kegiatan yang menyenangkan bagi anak mudatentunya agar dapat bermanfaat dan 
berpahala serta mengurangi perbuatan yang tidak baik.

\section{Struktur Kepengurusan Komunitas Gerakan Pemuda Hijrah}

\section{Sejarah terbentuknya Akun Youtube Pemuda Hijrah Shift Media}

Jamaah yang datang ke Masjid AlLathiif Bandung semakin lama semakin banyak hingga mencapai 4000 jamaah. Sehingga masjid Al-Lathiif tidak dapat menampung seluruh jamaah yang ingin mengikuti kajian. Oleh karena itu, pengurus Gerakan Pemuda Hijrah pada bulan september tahun 2017 memutuskan untuk membuat akun youtube Pemuda Hijrah Shift Media. Akun youtube Pemuda Hijrah Shift Media juga dibuat agar masyarakat yang berada jauh diluar kota dan ingin mengikuti kajian bisa melalui live streaming pada akun Pemuda Hijrah Shift Media. Selain itu bagi masyarakat yang tertinggal untuk mengikuti dan menonton kajian Pemuda Hijrah tidak perlu khawatir karena dengan dibuatnya akun youtube Pemuda Hijrah Shift Media masyarakat bisa menonton kajian Pemuda Hijrah kapanpun dan dimanapun mereka inginkan hanya dengan mengakses akun youtube Pemuda Hijrah Shift Media. Namun, alasan utama dibuatnya akun youtube Pemuda Hijrah Shift Media adalah untuk kebutuhan berdakwah dan memberikan konten yang positif bagi seluruh umat manusia.

Pengurus Gerakan Pemuda Hijrah memberikan nama akun youtube dengan sebutan SHIFT yang berarti bergerak, bergeser, atau dengan bahasa gaul anak muda adalah move on. Alasan dari pengurus Gerakan Pemuda Hijrah memberikan nama Shift juga sebagai strategi dakwah dari pengurus Gerakan
Pemuda Hijrah. Karena menurut pengurus Gerakan Pemuda Hijrah, jika dinamakan dengan nama yang to the point seperti Hijrah misalnya, pasti anak-anak muda sudah membatasi diri mereka sebelum pesan dakwahnya tersampaikan. Oleh karena itu, pengurus memutuskan untuk menggunakan nama kamuflase yaitu Shift Media sebagai nama dari akun youtube Gerakan Pemuda Hijrah.Hingga saat ini (22/04/2019), subscribes dari akun youtube Pemuda Hijrah Shift Media mencapai 277.140 subcribers, dengan jumlah 129 video dakwah.

Visi dari dibuatnya akun youtube Pemuda Hijrah Shift Media adalah ingin menjadi media dakwah yang menjadi sumber referensi bagi anak muda dan dapat diterima oleh anak muda.

\section{Komunitas Gerakan Pemuda Hijrah dalam Mengadopsi Inovasi Dakwah Online Pemuda Hijrah Shift Media}

Peneliti akan memaparkan data temuan penelitian yang telah dilakukan oleh peneneliti melalui kegiatan wawancara, observasi, dan dokumentasi Data dan temuan penelitian yang peneliti lakukan berkaitan dengan adopsi inovasi Komunitas Gerakan Pemuda Hijrah terhadap inovasi dakwah online pada akun youtube Pemuda Hijrah Shift Media. Berikut adalah data dan temuan penelitian yang peneliti dapatkan, yaitu:

\section{Proses Pengetahuan (knowledge)}

Pada tahap pertama proses adopsi inovasi ini, para informan telah berhasil melewati proses pengetahuan dikarenakan para informan telah mengetahui, memahami, serta memperoleh pengertian bahwa inovasi dakwah online akun youtube Pemuda Hijrah Shift Media bermanfaat bagi mereka dan juga 
masyarakat lainnya. Hal tersebut seperti yang dikemukakan oleh Dela, selaku informan pertama dalam penelitian ini, yang mengemukakan bahwa:

"saya mengetahui adanya akun youtube Pemuda Hijrah Shift Media, Akun youtube pemuda hijrah Shift Media ya tentang update kajian, yang tidak sempat datang dan hadir di kajiannya langsung bisa melihat di youtubenya, saya mengetahui dari Instagram Shift dan dari teman" 25

Della mengemukakan bahwa dirinya sudah mengetahui adanya akun youtube Pemuda Hijrah Shift Media, ia mengetahui adanya akun youtube Pemuda Hijrah Shift Media melalui instagram Gerakan Pemuda Hijrah yaitu @ shiftmedia.id dan juga dari temannya yang memberitahunya tentang keberadaan akun youtube Pemuda Hijrah Shift Media. Della sendiri memahami akun youtube Pemuda Hijrah Shift Media sebagai akun youtube dari Pemuda Hijrah yang mengupdate tentang kajian, ia juga menilai bahwa akun youtube Pemuda Hijrah Shift Media disediakan untuk orang-orang yang tidak bisa hadir ke kajian dari Gerakan Pemuda Hijrah secara langsung, karena dapat menonton melalui akun youtube Pemuda Hijrah Shift Media tersebut. Alisha Nur Laili, selaku informan kedua dalam penelitian ini, mengemukakan hal yang sama, bahwa:

"Iya, saya mengetahui ada akun youtube Pemuda Hijrah Shift Media. Yang saya ketahui tentang akun youtube Pemuda Hijrah Shift Media yaitu channel youtube yang mewadahi ceramah-ceramah dan dakwah. Jadi waktu itu saya melihat teman saya yang sempat ngepost, itu pertama kali saya tahu....." 26
Dari kutipan wawancara diatas dengan Alisha, Alisha mengatakan bahwa dirinya mengetahui adanya akun youtube Pemuda Hijrah Shift Media, dirinya mengetahui adanya akun youtube Pemuda Hijrah melalui instagram milik temannya. Alisha juga memahami bahwa akun youtube Pemuda Hijrah Shift Media adalah channel youtube yang mewadahi ceramah-ceramah dan juga dakwah.

Selanjutnya Hayyu sebagai informan ketiga dalam penelitian ini juga mengemukakan hal yang sama dengan Della dan juga Alisha, jika ia sudah mengetahui adanya akun youtube Pemuda Hijrah Shift Media, Hayyu mendapatkan informasi tentang adanya akun youtube Pemuda Hijrah Shift Media saat ia datang ke kajian yang diinformasikan secara langsung oleh ustad, pengurus Gerakan Pemuda Hijrah, serta oleh pembawa acara pada saat kajian berlangsung bahwa Pemuda Hijrah telah mempunyai akun youtube. Hayyu juga memahami bahwa akun youtube Pemuda Hijrah adalah channel youtube yang berisikan ilmu dakwah, reminder, bacaan surat-surat, dan juga kegiatan dari Pemuda Hijrah Shift itu sendiri. Jadi, menurutnya jika dirinya dan teman-teman lainnya yang berhalangan hadir untuk datang ke kajiannya secara langsung, ia dan temanteman tetap bisa menyaksikan kajian melalui akun youtube Pemuda Hijrah Shift Media. Berikut kutipan wawancara peneliti dengan Hayyu:

"Iya, saya mengetahui bahwa ada youtube Pemuda Hijrah Shift Media. Channel yang berisikan ilmu dakwah, reminder, bacaan surat-surat dan kegiatan dari Pemuda Hijrah Shift. Pertama kali belum ada youtubenya, ikut kajian terus diumumin dari 
ustadnya langsung serta oleh pembawa.....,27

Kemudian Irfan sebagai informan kelima dalam penelitian ini mengemukakan, bahwa ia:

"Iya mengetahui ada akun youtube dari Pemuda Hijrah Shift Media. Youtube Pemuda Hijrah Shift Media adalah youtube yang memiliki konten positif untuk anak-anak muda yang berhijrah agar bisa lebih menguatkan dan menambah wawasan tentang trend hijrah di zaman sekarang..... 28

Irfan selaku informan kelima dalam kutipan wawancara pada penelitian ini, mengemukakan bahwa ia telah mengetahui adanya akun youtube Pemuda Hijrah Shift Media, ia mengetauinya dari akun instagram Gerakan Pemuda Hijrah @shiftmedia.id, ia juga mengetahui bahwa akun youtube Pemuda Hijrah Shift Media adalah akun yang memiliki konten positif untuk anak-anak muda yang ingin atau sedang berhijrah agar lebih menguatkan dan menambah wawasan tentang trend hijrah saat ini.

Serta Anna, yang juga informan keempat dalam penelitian ini, mengemukakan juga hal yang sama, bahwa diinya sudah mengetahui adanya akun youtube Pemuda Hijrah Shift Media, Anna mendapatkan informasi terkait adanya akun youtube Pemuda Hijrah Shift Media dari akun instagram ustad Hanan Attaki yaitu@hanan_attaki. Ia juga mengetahui bahwa akun youtube Pemuda Hijrah Shift Media adalah suatu wadah atau media yang berisikan tentang video dakwah yang dikemas secara milenial sehingga mampu menarik anak-anak muda untuk menontonnya, serta ia juga mengetahui bahwa pada akun youtube Pemuda Hijrah Shift Media menyediakan live streaming saat kajian berlangsung.
"Ya, saya mengetahui adanya akun youtube Pemuda Hijrah. Yang saya ketahui tentang akun youtube Pemuda Hijrah Shift Media adalah suatu wadah atau media yang berisi tentang video dakwah yang dikemas secara milenial sehingga menurut saya anak-anak muda akan lebih tertarik, serta kita....."29

\section{Proses Persuasi (persuasion)}

Pada tahap persuasi ini para informan akan membentuk sikap baik, positif, mendukung serta berkenan ataupun membentuk sikap buruk, negatif, tidak mendukung, atau tidak berkenan terhadap inovasi. Sikap baik atau buruk diawali dahulu oleh persepsi atau pandangan awal personal masing-masing informan. Seperti kutipan wawancara yang dilakukan peneliti dengan Dela selaku informan, sebagai berikut:

"Bagus ya jadi kalau kita yang jarang datang ke kajian atau masjid bisa dengerin juga dari kajian di youtube, motivasi juga menurut saya. Ya bagus, senang sikapnya positif dan mendukung, 30

Persepsi dan pandangan awal dari Dela terhadap adanya inovasi dakwah online pada akun youtube Pemuda Hijrah Shift Media adalah baik, sehingga sikap atau persuasi yang ditimbulkan oleh Della juga baik terhadap inovasi dakwah online tersebut. Kemudian Alisha Nur Laili selaku informan kedua berpendapat bahwa:

"Menurut saya menarik, karena dari dakwah dan ceramahnya juga buat kita yang anak muda masuk dan dengan medianya juga yang melalui media sosial ya bagus. Kalau sikap saya sih positif ya, 
menurut saya bermanfaat bisa didengar oleh banyak orang." 31

Persepsi dan pandangan dari Alisha Nur Laili selaku informan kedua juga menghasilkan nilai yang baik yang akhirnya menimbulkan sikap atau persuasi baik dan positif pula didalam diri Alisha Nur Laili. Selanjutnya informan ketiga yaitu Hayyu yang berpendapat bahwa:

"Bagus ya. Karena tidak semua orang bisa datang ke kajiannya Usttad, siapa tahu ada halangan atau jauh dari Bandung tapi mereka bisa tetap menonton kajian melalui youtube. Sikap saya sangat positif",32

Persepsi dan pandangan awal dari Hayyu adalah inovasi yang dibuat sangat bermanfaat dan memudahkan para anggota Komunitas agar tetap bisa menyaksikan kajian walaupun tidak datang langsung ke kajian yang sedang berlangsung. Yang pastinya menimbulkan sikap persuasi yang baik di dalam diri Hayyu. Anna selaku informan keempat berpendapat dengan singkat bahwa:

"Pendapat saya yaitu sangat bagus dan sangat positif" 33

Persepsi dan pandangan awal Anna menimbulkan sikap dan persuasi yang baik dan positif. Serta yang terakhir yaitu Irfan informan kelima yang berpendapat bahwa:

"Pendapat saya pertama kali mendengar bahwa Pemuda Hijrah membuat akun youtube ya pencetus video one minute booster kan Shift ya pertama kali di Indonesia juga, ya pendapat saya Pemuda Hijrah Shift berhasil membuat kita semua merenung walaupun berawal dari hanya satu menit....."34
Menurut Irfan, video yang dibuat oleh Shift untuk yang pertama kalinya di Indonesia yaitu video one minute booster. Walaupun video tersebut hanya berdurasi satu menit saja namun menurutnya video tersebut membawa dampak yang membuat semua orang merenung.

\section{Proses Keputusan (Decision)}

Dalam tahap ini para informan telah sampai kepada tahapan pengambilan keputusan terkait sebuah inovasi yang dikenalkan kepada mereka. Dalam hal ini, suatu inovasi sudah sampai pada tahap pengadopsian maupun penolakan oleh para informan. Pada tahap keputusan inilah yang menentukan informan memasuki tahapan berikutnya atau tidak dan menentukan para informan untuk mengadopsi suatu inovasi atau menolak untuk mengadopsi suatu inovasi yang ada.

Dalam proses keputusan inovasi ini juga, terdapat jangka waktu yang dilihat mulai dari informan mengetahui sampai akhirnya memutuskan untuk menerima ataupun menolak inovasi yang ada tersebut. Seperti yang dilakukan oleh Dela, Anna, dan Irfan, yang langsung memutuskan untuk mengadopsi inovasi dalam hal ini menonton dan mensubscribe akun youtube Pemuda Hijrah Shift Media.

"Langsung mensubscribe dan menonton juga, baru tahun ini awal tahun 2019,35

"Langsung mensubscribe dan langsung nonton terus, dan udah dari lama, awal dibuat 2 tahun lalu"36

"Menonton langsung dan mensubscribe langsung, pada tahun 2017'37 
Ketiga informan yaitu Della, Anna dan Irfan sesuai kutipan wawancara diatas bersama dengan peneliti, mereka mengemukakan bahwa mereka langsung menonton dan juga mensubscribe akun youtube Pemuda Hijrah Shift Media. Berbeda dengan Della, Anna, dan Irfan, Alisha Nur Laili sebagai informan kedua memutuskan untuk memilih menonton video dakwah pada akun youtube Pemuda Hijrah Shift Media terlebih dahulu, dan kemudian baru mensubscribenya.

"Saya nonton dulu kemudian baru saya mensubscribe. Kira-kira mungkin 5 atau 6 bulan yang lalu, kalau teman saya itu ngepost nya udah sekitar 8 bulan yang lalu tapi saya belum nonton youtubenya, saat saya ada permasalahan hidup baru saya menonton youtube Pemuda Hijrahnya"38

Penilaian lain diungkapkan oleh Hayyu selaku informan ketiga, ketika ia mengambil keputusan untuk mengadopsi inovasi, ia tidak mensubscribe akun youtube Pemuda Hijrah Shift Media. Walaupun ia tidak mensubscribe akun youtube Pemuda Hijrah, tetapi ia intens menonton video yang ada pada akun youtube Pemuda Hijrah Shift Media.

"Sebenernya karna saya sering datang ke kajian dan kebetulan rumahnya deket di Bandung juga, jadi deket dan lebih sering datang ke kajian langsung daripada nonton youtube sih, tapi kalau saya lagi berhalangan datang ke kajian saya nonton dari youtube atau tema-tema yang saya....." 39

\section{Proses Penerapan (Implementation)}

Tahap penerapan adalah tahap dimana pertama kali para informan menerapkan dan juga menggunakan inovasi tersebut. Informan yang sudah menerapkan dan menggunakan inovasi tersebut dikatakan telah mengadopsi inovasi atau disebut dengan adopter. Pada tahap penerapan ini adopter akan menghasilkan suatu penilaian dimana penilaian tersebut menentukan adopter untuk melanjutkan penggunaan inovasi atau berhenti dan menolak menggunakan inovasi tersebut.

Pada tahap sebelumnya yaitu tahap keputusan, para informan yang tergabung dalam Komunitas Gerakan Pemuda Hijrah telah memutuskan untuk mengadopsi inovasi dakwah online akun youtube Pemuda Hijrah Shift Media. Alisha Nur Laili dan Hayyu mengemukakan bahwa:

"Menurutku setelah saya mengadopsi youtube Pemuda Hijrah sih sangat membawa pengaruh positif ke saya pribadi, jadi merasa terbantu jadi jika dulu kalau mau mendengar ceramah harus ke masjid atau menonton tv itu pun tidak tentu waktunya dan terikat. Kalau sekarang setelah mensubscribe....."40 Hal yang sama juga dikemukakan oleh informan lainnya yaitu Della, Anna dan Irfan ketika mereka menggunakan atau menerapkan inovasi dakwah online pada akun youtube Pemuda Hijrah Shift Media didalam kehidupan sehari-hari, terlihat dari kutipan wawancara dibawah ini:

"Memberikan efek positif buat kita, efek positif nya yaitu saya lebih melakukan hal-hal yang baik dan juga lebih penting untuk dikerjakan dan meninggalkan hal-hal atau kegiatan-kegiatan yang tidak baik dan tidak penting untuk dikerjakan" 41 


\section{Proses Konfirmasi (confirmation)}

Dalam tahap konfirmasi ini, informan sudah sampai pada tahap dimana informan mulai mencari penguatanpenguatan terhadap keputusannya terkait menolak maupun menerima suatu inovasi untuk tetap diadopsi. Penguatanpenguatan diatas adalah penguatan dalam artian apakah informan tersebut puas atau tidak puas terhadap inovasi yang sudah digunakannya tersebut. Selain itu pada tahap konfirmasi ini, jika para informan merasakan kepuasan setelah menggunakan inovasi yang ada, maka para informan juga akan mengajak, memeberitahukan, serta merekomendasikan kepada orang lain untuk ikut mengdopsi inovasi tersebut. Dela mengatakan bahwa:

"Iya karena setiap ada kegiatan atau kajian suka langsung diupdate dan juga ada live streamingnya dari youtube Pemuda Hijrah nya, jadi ya puas. Iya info juga ke teman teman dan keluarga saya"42

Sesuai hasil wawancara peneliti dengan Dela diatas, Dela mengemukakan bahwa akun youtube Pemuda Hijrah Shift Media selalu mengupdate dan melakukan siaran langsung (live streaming) setiap ada kegiatan atau kajian yang diselenggarakan. Oleh karena itu, dirinya puas telah mengadopsi inovasi akun youtube Pemuda Hijrah Shift Media. Dela juga mengungkapkan bahwa dirinya menginformasikan kepada teman dan keluarganya tentang akun youtube Pemuda Hijrah Shift Media.

Selanjutnya, Anna selaku informan keempat dan Irfan selaku informan kelima yang mengemukakan kepada penelitiu bahwa mereka sangat puas dengan adanya inovasi dakwah online dari akun youtube Pemuda Hijrah Shift Media, mereka mengemukakan bahwa:

"Ya puas banget, karena membuat edukasi sangat positif dan sangat merubah. Dan juga youtubenya lebih teratur visualnya juga. Sepertinya Pemuda Hijrah adalah awal-awal semua dakwah media. jadi, awalnya dakwah dari media itu dari pertamanya memang Pemuda Hijrah dulu....."43

Dari hasil wawancara peneliti dengan Anna dan Irfan diatas, dapat dilihat alasan Anna dan Irfan merasa puas dengan akun youtube Pemuda Hijrah Shift Media dikarenakan akun youtube Pemuda Hijrah Shift Media mempunyai konten yang positif yang membawa dampak atau pengaruh baik untuk mereka berdua. Karena mereka merasa puas telah mengadopsi akun yoitube Pemuda Hijrah Shift Media, maka merakapun merekomendasikan akun youtube Pemuda Hijrah Shift Media kepada orang-orang sekitarnya.

Alisha Nur Laili yaitu informan kedua dan Hayyu yaitu informan ketiga juga mengemukakan hal yang sama seperti Anna dan Irfan, bahwa mereka merasa puas dengan adanya akun youtube Pemuda Hijrah Shift Media. Alisha dan Hayyu pun juga merekomendasikan akun youtube Pemuda Hijrah Shift Media kepada teman-temannya. Hal tersebut diungkapakan oleh Alisha dan Hayyu seperti dibawah ini:

"Saya merasa puas dengan adanya akun youtube Pemuda Hijrah Shift Media. Iya saya merekomendasikan ke beberapa teman-teman" 44 


\section{Alasan Komunitas Gerakan Pemuda Hijrah Mengadopsi Inovasi Dakwah Online Pemuda Hijrah Shift Media}

Pada wawancara yang sudah dilakukan oleh peneliti terhadap informan terkait alasannya mengadopsi inovasi dakwah online pada akun youtube Pemuda Hijrah Shift Media, didapatkan data dan temuan penelitian seperti berikut ini:

Della selaku informan pertama, mengemukakan bahwa alasannya mengadopsi inovasi dakwah online pada akun youtube Pemuda Hijrah Shift Media dikarenakan ia merasa akun youtube Pemuda Hijrah Shift Media bagus dan telah berhasil memotivasi dirinya untuk menjadi seseorang yang lebih baik dari waktu ke waktu, menurut Della juga akun youtube Pemuda Hijrah Shift Media lebih bermanfaat dibandingkan akun youtube lainnya yang menurutnya hanya hiburan semata. Della mengatakan bahwa:

"Ya alasannya karena bagus dan memotivasi. Dibandingkan yang lain, lebih bermanfaat, karena di youtube kan banyak video-video yang lain juga tapi tidak ada manfaatnya sih menurut aku hanya hiburan semata, tapi kalau Pemuda Hijrah Shift Media ya bukan hanya untuk hiburan semata....." 45

Sama seperti halnya Della yang mengadopsi akun youtube Pemuda Hijrah dikarenakan menurutnya lebih bermanfaat, Alisha Nur Laili selaku informan kedua mengemukakan bahwa alasannya mengadopsi inovasi dakwah online pada akun youtube Pemuda Hijrah Shift Media, yaitu:

"Alasannya itu karena menarik dan juga bermanfaat, ya jadinya daripada menonton youtube kadangkadang suka tidak penting yang dilihat, jadi yasudah sekarang lebih bermanfaat dan lebih baik. Menariknya itu dalam segi pembawaan dari udztad Hanannya yang....." 46

Alisha beralasan bahwa ia mengadopsi akun youtube Pemuda Hijrah Shift Media karena ia merasa akun youtube Pemuda Hijrah Shift Media menarik dan juga bermanfaat dan lebih baik bagi dirinya. Menurutnya akun youtube Pemuda Hijrah Shift Media menarik dikarenakan pembawaan dari udztad Hanan Attaki yang tidak kaku di dalam video youtube Pemuda Hijrah Shift Media, serta gaya bahasa dari udztad Hanan Attaki yang juga seperti anak muda sehingga mudah diterima dan diserap oleh anak-anak muda sepertinya. Sedangkan menurut Alisha akun youtube Pemuda Hijrah Shift Media bermanfaat karena dengan dirinya menonton youtube Pemuda Hijrah Shift Media ia pasti mendapatkan pelajaran dan nilai-nilai agama yang penting dan nilai-nilai kehidupan yang penting sehingga bermanfaat untuk dirinya dan dirinya bisa mengkoreksi diri dari hal-hal yang buruk sehingga bisa menjadi lebih baik untuk kedepannya.

Kemudian Hayyu selaku informan ketiga juga mengemukakan bahwa alasannya mengadopsi inovasi dakwah online pada akun youtube Pemuda Hijrah Shift Media, yaitu:

"Alasan pertama yang pasti untuk menambah ilmu dan mendengarkan kajian dari Utstad Hanan Attaki. Serta selain itu karena ada kegiatan-kegiatan lain dari Pemuda Hijrah yang diupdate di youtubenya, jadi kita bisa melihat apa saja kegiatan-kegiatan yang dilakukakan oleh Pemuda Hijrah. 
Tapi buat saya yang paling positif tetap tentang kajian ilmunya",47

Hayyu seperti kutipan wawancara diatas, mengatakan bahwa alasan utama dirinya mengadopsi inovasi dakwah online pada akun youtube Pemuda Hijrah Shift Media dikarenakan dengan mengadopsi akun youtube Pemuda Hijrah Shift Media bisa menambah ilmu dan bisa mendengarkan kajian dari ustad Hanan Attaki, serta alasan lain dirinya mengadopsi akun youtube Pemuda Hijrah Shift Media adalah mengetahui kegiatankegiatan lain yang dilakukan oleh Pemuda Hijrah yang diupdate pada akun youtube Pemuda Hijrah Shift Media. Selanjutnya, Anna selaku informan keempat yang mengemukakan alasannya mengadopsi inovasi dakwah online pada akun youtube Pemuda Hijrah Shift Media sama seperti Della dan Alisha, yaitu:

"Karena memang akunnya bermanfaat, seperti yang saya katakan sebelumnya bermanfaat karena membawa pengaruh yang positif. Dan memang masuk untuk semua kalangan dan berisi nasihat untuk anak muda yang sukanya bermain, serta pembawaanya yang santai,....." 48

Anna mengemukakan bahwa ia mengadopsi akun youtube Pemuda Hijrah Shift Media karena menurutnya akun youtube Pemuda Hijrah Shift Media bermanfaat karean membawa pengaruh yang baik dan positif dan dapat masuk ke seluruh kalangan, serta video yang ada pada akun youtube Pemuda Hijrah Shift Media mampu menasehati anak-anak muda yang suka bermain seperti dirinya, dan juga pembawaannya yang santai membuat dirinya mengadopsi inovasi dakwah online akun youtube Pemuda
Hijrah Shift Media. Ia juga merasa akun youtube Pemuda Hijrah Shift Media sesuai untuk dirinya. Serta informan terakhir yaitu Irfan yang mengemukakan dengan singkat alasannya mengadopsi inovasi dakwah online pada akun youtube Pemuda Hijrah Shift Media, bahwa:

"Alasan utamanya karena akun youtube Pemuda Hijrah sangat membawa perubahan untuk diri saya pribadi, perubahannya itu saya sangat merasakan ketenangan dalam diri saya, yang sebelumnya saya suka galau, setelah saya menonton video youtube....."49

Menurut Irfan dalam kutipan wawancara diatas, ia mengadopsi inovasi dakwah online pada akun youtube Pemuda Hijrah Shift Media karena akun youtube Pemuda Hijrah Shift Media sangat membawa perubahan untuk dirinya, serta ia merasakan ketenangan ketika ia menonton video yang ada di akun youtube Pemuda Hijrah Shift Media. Dirinya menjadi jauh lebih tenang dan selalu membawa dan mengingat Allah di segala kegiatannya, menurutnya perubahan itu dirasakan oleh rohani dalam dirinya.

Dapat disimpulkan dari pembahasan diatas, temuan penelitian bahwa informan yang tergabung dalam Komunitas Gerakan Pemuda Hijrah pada penelitian ini telah melewati tahap konfirmasi atau pemantapan keputusan. Inovasi yang mudah digunakan serta manfaat dan juga kepuasaan yang langsung didapatkan menjadi salah satu mengapa Komunitas Gerakan Pemuda Hijrah menerima dan melanjutkan untuk tetap dan terus mengadopsi inovasi ini bahkan Komunitas Gerakan Pemuda Hijrah dalam tahap konfirmasi ini mereka 
merekomendasikan akun youtube Pemuda Hijrah Shift Media kepada orang lain.

Peneliti juga menyimpulkan bahwa Komunitas Gerakan Pemuda Hijrah sudah bisa disebut sebagai adopter, karena kelima informan yang tergabung ke dalam Komunitas Gerakan Pemuda Hijrah dalam penelitian ini telah mengadopsi inovasi dakwah online pada akun youtube Pemuda Hijrah Shift Media dan telah melewati proses adopsi inovasi sebagaimana dengan lima tahapan proses pada teori difusi inovasi yang dikemukakan oleh Everett M. Rogers.

\section{Analisis Alasan Mengadopsi Inovasi Dakwah Online Pemuda Hijrah Shift Media}

Everett M. Rogers dalam bukunya yang berjudul Diffusions of Innovation menekankan bahwa difusi mengutamakan pada terjadinya perubahan tingkah laku yang nyata yaitu sikap menerima atau menolak inovasi baru tersebut. Untuk menghasilkan tingkah laku yang nyata sesuai yang dimaksud, diperlukan tahapan difusi yang juga mempengaruhi adopsi inovasi itu sendiri. Hasil dari adopsi inovasi adalah efek yang terjadi dari adanya proses difusi inovasi. Proses difusi inovasi dikatakan penting karena didalamnya terdapat informasi yang akan diterima oleh masyarakat yang disebarkan melalui saluran komunikasi baik melalui saluran komunikasi interpersonal maupun saluran komunikasi media.

Dela mengungkapan alasan dirinya mengadopsi inovasi akun youtube Pemuda Hijrah Shift Media karena menurutnya akun youtube Pemuda Hijrah Shift Media bagus dan memotivasi dirinya. Menurutnya juga, akun youtube Pemuda Hijrah Shift Media lebih bagus dan lebih bermanfaat dibandingkan akun- akun youtube yang lainnya. Menurutnya banyak video-video lain di youtube yang tidak ada manfaatnya yang menurutnya hanya hiburan semata. Tetapi dengan menonton video youtube Pemuda Hijrah Shift Media dirinya bukan hanya mendapatkan hiburan semata tetapi dirinya juga mendapatkan manfaat yaitu dirinya lebih termotivasi menjadi seseorang yang lebih baik lagi dari waktu ke waktu.

Alisha sebagai informan kedua dalam penelitian ini, mengungkapakan bahwa alasan ia mengadopsi inovasi akun dakwah online akun youtube Pemuda Hijrah Shift Media karena dirinya merasa akun youtube Pemuda Hijrah Shift Media menarik dalam segi pembawaan yaitu dari ustad Hanan Ataki yang menurutnya tidak kaku dalam penyampaian ceramah di dalam videonya, gaya bahasanya juga menurutnya yang seperti anak muda jadi lebih mudah diterima dan dicerna oleh anak-anak muda seperti dirinya dan menurutnya juga akun youtube Pemuda Hijrah Shift Media bermanfaat karena dengan menonton video yang ada pada akun youtube Pemuda Hijrah Shift Media pasti mendapatkan pelajaran dan nilainilai agama yang penting, sehingga berhasil membuat dirinya menjadi pribadi yang lebih baik lagi. Alisha juga berpendapat bahwa dibandingkan ia menonton akun youtube yang lain yang tidak penting untuk ditonton dan dilihat, lebih baik dirinya menonton akun youtube Pemuda Hijrah Shift Media yang memang benar-benar memiliki manfaat jika ditonton.

Hayyu beralasan dirinya mengadopsi inovasi dakwah online akun youtube Pemuda Hijrah Shift Media karena untuk menambah ilmu dan mendengarkan kajian dari ustad Hanan 
Attaki itu sendiri. Selain itu juga ia beralasan agar bisa melihat dan menyaksikan kegiatan-kegiatan lain dari Pemuda Hijrah yang diupdate ke dalam youtube Pemuda Hijrah Shift Media. Tetapi menurut Hayyu alasan terpenting untuk dirinya mengadopsi dan menggunakan inovasi dari akun youtube Pemuda Hijrah Shift Media karena kajian ilmunya.

Anna mengaku alasan dirinya mengadopsi inovasi dakwah online akun youtube Pemuda Hijrah Shift Media karena menurutnya akun youtube Pemuda Hijrah Shift Medianya memang bermanfaat karena membawa pengaruh yang positif serta sesuai dan cocok untuk semua kalangan. Menurutnya juga, akun youtube Pemuda Hijrah Shift Media berisikan nasihat-nasihat untuk anak muda yang suka bermain, serta pembawaan dakwahnya yang santai sehingga dakwahnya tersebut mudah masuk ke kalangan muda seperti dirinya dan teman-temannya. Tetapi alasan utama Anna mengadopsi inovasi dakwah online akun youtube Pemuda Hijrah Shift Media adalah karena sesuai dengan dirinya yang anak muda.

Informan terakhir pada penelitian ini yaitu Irfan, yang menegemukakan bahwa alasan utama dirinya mengadopsi inovasi akun youtube Pemuda Hijrah Shift Media adalah karena menurutnya akun youtube Pemuda Hijrah Shift Media sangat membawa perubahan untuk dirinya pribadi. Ia mengatakan bahwa membawa perubahan itu karena ia mendapatkan ketenangan dalam dirinya dan menjadi selalu membawa dan mengingat Allah SWT disetiap kegiatan yang ia lakukan. Ia juga mengaku jika sebelumnya ia sering merasa galau namun setelah dirinya mengadopsi akun youtube
Pemuda Hijrah Shift Media ia merasa jauh lebih merasakan ketenangan rohani dalam dirinya.

Pada wawancara mendalam yang sudah dilakukan oleh peneliti terhadap kelima informan terkait alasannya mengadopsi inovasi dakwah online pada akun youtube Pemuda Hijrah Shift Media, peneliti menganalisis dan menarik kesimpulan bahwa alasan Komunitas Pemuda Hijrah dalam mengadopsi inovasi dakwah online pada akun youtube Pemuda Hijrah Shift Media dikarenakan faktor dari adanya karakteristik inovasi itu sendiri yaitu inovasi dakwah online pada akun youtube Pemuda Hijrah Shift Media.

Lima karakteristik inovasi yang dikemukakan oleh Everett M. Rogers, ialah pertama, keuntungan relatif (Relative Advantage), kedua yaitu kompatibel atau kesesuaian (Compatibility), ketiga ialah kompleksitas (Complexity), keempat adalah triabilitas (Triability), serta kelima dapat Diobservasi (Oservability).

Pada hasil wawancara penelitian ini juga, peneliti menemukan temuan penelitian yaitu dari kelima karakteristik inovasi yang dikemukakan oleh Rogers diatas, hanya ada dua karakteristik inovasi yang berpengaruh kepada adopsi inovasi Komunitas Gerakan Pemuda Hijrah sedangkan ketiga karakteristik lainnya tidak berpengaruh terhadap adopsi inovasi Komunitas Gerakan Pemuda Hijrah pada inovasi dakwah online akun youtube Pemuda Hijrah Shift Media. Kedua karakteristik inovasi tersebut adalah adanya keuntungan relatif (Relative Advantage) serta adanya kompatibel atau kesesuaian (Compability). 
Keuntungan relative (Relative Advantage) adalah bagaimana suatu inovasi yang baru dapat dikatakan lebih baik dari inovasi sebelumnya atau justru tidak lebih baik dari inovasi sebelumnya. Tolak ukur dari keuntungan relatif adalah bagaimana seorang adopter itu sendiri merasakan langsung dampak dari manfaat inovasi tersebut yang membuat dirinya menjadi puas ataupun tidak puas pada sebuah inovasi. Semakin besar keuntungan relatif yang dirasakan oleh individu semakin cepat pula suatu inovasi tersebut diadopsi oleh individu.

Sedangkan kompatibel atau kesuasuaian (Compatibility) berkaitan dengan bagaimana suatu inovasi itu dapat dikatakan sesuai dengan kondisi, kebudayaan dan nilai-nilai di dalam masyarakat itu sendiri, serta apakah inovasi tersebut sesuai dengan kebutuhan yang ada pada masyarakat tersebut atau tidak. Jika sesuai dengan kondisi, kebudayaan, nilai-nilai, serta kebutuhan yang ada di masyarakat maka suatu inovasi itu juga akan mudah diadopsi oleh masyarakat, namun jika tidak sesuai dengan kondisi, kebudayaan, nilai-nila, serta kebutuhan yang ada di masyarakat maka suatu inovasi akan sulit diadopsi bahkan tidak akan diadopsi oleh masyarakat.

Pada hasil wawancara yang dilakukan peneliti dengan informan, dapat dilihat bahwa kelima informan yaitu Della, Alisha, Hayyu, Anna, serta Irfan menekankan bahwa alasan mereka mengadopsi inovasi dakwah online pada akun youtube Pemuda Hijrah Shift Media dikarenakan adanya keuntungan yang mereka dapatkan setelah mengadopsi inovasi akun youtube Pemuda Hijrah Shift Media, yaitu mereka merasa mendapatkan manfaat dan juga motivasi, sehingga mereka merasa puas sudah mengadopsi akun youtube Pemuda Hijrah Shift Media.

Selain itu pula, mereka beralasan mengadopsi inovasi dakwah online akun youtube Pemuda Hijrah Shift Media juga dikarenakan inovasi dakwah online dari akun youtube Pemuda Hijrah Shift Media lebih menarik dibandingkan inovasi lainnya, dan sesuai untuk mereka dan untuk semua kalangan, terutama sesuai untuk para remaja yang sukanya bermain, serta membawa dampak atau perubahan yang sangat positif bagi Komunitas Pemuda Hijrah itu sendiri, dan juga tentunya untuk seluruh masyarakat.

\section{Kesimpulan}

Berdasarkan hasil penelitian, maka dapat disimpulkan bahwa, pengalaman pengetahuan dari Komunitas Gerakan Pemuda Hijrah adalah sudah mengetahui dan telah memahami tentang adanya akun youtube Pemuda Hijrah Shift Media. Komunitas Gerakan Pemuda Hijrah mengetahui adanya inovasi akun youtube Pemuda Hijrah Shift Media melalui dua saluran komunikasi yaitu saluran komunikasi interpersonal dan saluran komunikasi media.

Pengalaman persuasi dari Komunitas Gerakan Pemuda Hijrah memberikan sikap baik yang positif dan mendukung inovasi dakwah online yaitu akun youtube Pemuda Hijrah Shift Media. Pengalaman keputusan dari Komunitas Gerakan Pemuda Hijrah ialah mengadopsi inovasi dakwah online dengan cara mensubscribe dan menonton akun youtube Pemuda Hijrah Shift Media. Pengalaman implementasi Komunitas Gerakan Pemuda Hijrah secara umum sudah dilakukan sejak pertama kali mereka mengetahui akun youtube Pemuda Hijrah Shift Media. Pengalaman konfirmasi dari 
Komunitas Gerakan Pemuda Hijrah ialah Komunitas Pemuda Hijrah merasakan kepuasan setelah mengadopsi akun youtube Pemuda Hijrah Shift Media dan Komunitas Gerakan Pemuda Hijrah merekomendasikan inovasi akun youtube Pemuda Hijrah Shift Media.

Alasan Komunitas Gerakan Pemuda Hijrah mengadopsi inovasi dakwah online akun youtube Pemuda Hijrah Shift Media adalah karena akun youtube Pemuda Hijrah Shift Media memiliki kesesuaian dan memberikan keuntungan kepada Komunitas Pemuda Hijrah. Keuntungan yang didapatkan oleh Komunitas Gerakan Pemuda Hijrah dari mengadopsi inovasi akun youtube Pemuda Hijrah Shift Media adalah mendapatkan manfaat yaitu menambah ilmu agama dan mendapatkan nilai-nilai kehidupan, berdampak positif yaitu video dakwah pada akun youtube Pemuda Hijrah Shift Media mengingatkan dan mengajak untuk menjadi lebih baik lagi, memotivasi yaitu Komunitas Gerakan Pemuda Hijrah menjadi termotivasi untuk menjadi pribadi yang lebih baik lagi dari waktu ke waktu, dan juga konten youtubenya yang menarik dan sesuai untuk usia muda.

\section{Catatan kaki:}

1 Fathul Wahid, E-dakwah, Dakwah Melalui Internet, (Yogyakarta: Gava Media, 2004), hal. 30

2 Moh.Ali Azis, Ilmu Dakwah Edisi Revisi, (Jakarta: Kencana, 2009), hal. 47

${ }^{3}$ Deddy Mulyana, Filsafat Komunikasi. Tradisi dan Metode Fenomenologi, (Bandung: PT.Remaja Rosdakarya, 2013), hal. 425
${ }^{4}$ Deddy Mulyana, Filsafat Komunikasi. Tradisi dan Metode Fenomenologi, hal. 427

${ }^{5}$ Cresswell, J. W. Research Design: Quantitaive And Qualitative Approach, (London: Sage, 1994), hal. 53

${ }^{6}$ Everett M. Rogers, Diffusion of Innovation, page. 11

7 Everett M. Rogers, Diffusion of Innovation, page. 163

${ }^{8}$ Masyhur Amin, Dakwah Islam dan Pesan Moral, (Yogyakarta: Al Amin Press, 1997), hal. 8

9 Masyhur Amin, Dakwah dan Pesan Moral, hal. 10

10 Tata Sukayat, Quantum Dakwah, (Jakarta: Rineka Cipta, 2009), hal.1

${ }^{11}$ Saerozi, Ilmu Dakwah, (Yogyakarta: Penerbit Ombak Dua, 2013), hal. 11

${ }^{12}$ Djamaludin Ancok, Psikologi Kepemimpinan \& Inovasi, hal. 23

13 Asmuni Syukir, Dasar-Dasar Strategi Dakwah Islam, hal. 165

${ }^{14}$ Wahyu Ilahi, Komunikasi Dakwah, hal. 110

15 Fathul Wahid, E-Dakwah: Dakwah Melalui Internet, hal. 27

16 Pardianto, Jurnal Komunikasi Islam Meneguhkan Dakwah melalui New Media, (Fakultas Dakwah Sunan Ampel, 2013), hal. 10

${ }^{17}$ Wahyu Ilahi, Komunikasi Dakwah, hal. 110

${ }^{18}$ Moh. Ali Aziz, Ilmu Dakwah, hal.155

${ }^{19}$ Wahyu Ilahi, Komunikasi Dakwah, hal. 110

${ }^{20}$ Moh.Ali Aziz,Ilmu Dakwah, hal. 156

${ }^{21}$ Moh Ali Aziz, Ilmu Dakwah, hal. 157

22 Alo Liliweri, Komunikasi Antar Personal, (Jakarta: Prenada Media Group, 2015), hal. 288

${ }^{23}$ Solis\&Breakendridge, Putting the Public Back in Public Relation: How media Social is Reinventing the Agging Business of PR, (New Jersey: Pearson Education, 2009), hal. 3

${ }^{24}$ Alo Liliweri, Komunikasi Antar Personal, hal. 288

${ }^{25}$ Wawancara pribadi dengan Dela di Masjid Trans Studio Bandung, hari Rabu 26 Juli 2019, Pukul 17.32WIB

${ }^{26}$ Lihat lampiran transkrip wawancara peneliti dengan Alisha Nur Laili di Masjid Trans Studio Bandung, hari Rabu 26 Juli 2019, Pukul 17.40 WIB

${ }^{27}$ Lihat lampiran transkrip wawancara peneliti dengan Hayyu di Masjid Trans Studio Bandung, hari Rabu 26 Juli 2019, Pukul 17.51 WIB

${ }^{28}$ Lihat lampiran transkrip wawancara peneliti dengan Irfan di Masjid Trans Studio Bandung, hari Rabu 26 Juli 2019, Pukul 18.37 WIB

${ }^{29}$ Lihat lampiran transkrip wawancara peneliti dengan Anna di Masjid Trans Studio Bandung, hari Rabu 26 Juli 2019, Pukul 18.09 WIB 
30 Wawancara pribadi dengan Della di Masjid Trans Studio Bandung, hari Rabu 26 Juli 2019, Pukul 17.32 WIB

${ }^{31}$ Wawancara pribadi dengan Alisha Nur Laili di Masjid Trans Studio Bandung, hari Rabu 26 Juli 2019, Pukul 17.40 WIB

32 Wawancara pribadi dengan Hayyu di Masjid Trans Studio Bandung, hari Rabu 26 Juli 2019, Pukul 17.51 WIB

33 Wawancara pribadi dengan Anna di Masjid Trans Studio Bandung, hari Rabu 26 Juli 2019, Pukul 18.09 WIB

${ }^{34}$ Lihat lampiran transkrip wawancara peneliti dengan Irfan di Masjid Trans Studio Bandung, hari Rabu 26 Juli 2019, Pukul 18.37 WIB

35 Wawancara pribadi dengan Della di Masjid Trans Studio Bandung, hari Rabu 26 Juli 2019, Pukul 17.32 WIB

36 Wawancara pribadi dengan Anna di Masjid Trans Studio Bandung, hari Rabu 26 Juli 2019, Pukul 18.09 WIB

37 Wawancara pribadi dengan Irfan di Masjid Trans Studio Bandung, hari Rabu 26 Juli 2019, Pukul 18.37 WIB

38 Wawancara pribadi dengan Alisha Nur Laili di Masjid Trans Studio Bandung, hari Rabu 26 Juli 2019, Pukul 17.40 WIB

${ }^{39}$ Lihat lampiran transkrip wawancara peneliti dengan Hayyu di Masjid Trans Studio Bandung, hari Rabu 26 Juli 2019, Pukul 17.51 WIB

${ }^{40}$ Lihat lampiran transkrip wawancara peneliti dengan Alisha Nur Laili di Masjid Trans Studio Bandung, hari Rabu 26 Juli 2019, Pukul 17.40 WIB

41 Wawancara pribadi dengan Anna di Masjid Trans Studio Bandung, hari Rabu 26 Juli 2019, Pukul18.09 WIB

42 Wawancara pribadi dengan Della di Masjid Trans Studio Bandung, hari Rabu 26 Juli 2019, Pukul 17.32 WIB

${ }^{43}$ Lihat lampiran transkrip wawancara peneliti dengan Anna di Masjid Trans Studio Bandung, hari Rabu 26 Juli 2019, Pukul 18.09 WIB

${ }^{44}$ Wawancara pribadi dengan Alisha Nur Laili di Masjid Trans Studio Bandung, hari Rabu 26 Juli 2019, Pukul 17.40 WIB

45 Lihat lampiran transkrip wawancara peneliti dengan Della di Masjid Trans Studio Bandung, hari Rabu 26 Juli 2019, Pukul 17.32 WIB

${ }^{46}$ Lihat lampiran transkrip wawancara peneliti dengan Alisha Nur Laili di Masjid Trans Studio Bandung, hari Rabu 26 Juli 2019, Pukul 17.40 WIB

47 Wawancara pribadi dengan Hayyu di Masjid Trans Studio Bandung, hari Rabu 26 Juli 2019, Pukul17.51 WIB
48 Wawancara pribadi dengan Anna di Masjid Trans Studio Bandung, hari Rabu 26 Juli 2019, Pukul18.09 WIB

49 Wawancara pribadi dengan Irfan di Masjid Trans Studio Bandung, hari Rabu 26 Juli 2019, Pukul 18.37 WIB

\section{DAFTAR PUSTAKA}

Abdurrahman, Fatoni, Metodelogi Penelitian dan Tehnik Penyusunan Skripsi. Jakarta: PT. Rinekha Cipta, 2006.

Agoeng Nugroho, Teknologi Komunikasi. Yogyakarta: Graha Ilmu, 2010.

Amin Ahsan Ishlahi, Metode Dakwah Menuju Jalan Allah. Jakarta: Litera Antara Nusa, 1985.

Anis Fitiani, "Analisis Isi Pesan Dakwah Udztad Hanan Attaki dalam Akun Youtube Pemuda Hijrah". KPI, UIN Jakarta, 2018.

Abu Bakar Jabir Al-Jazairi, Aqidah Seorang Mukmin. Solo: Daarul Fikri, 1994.

Abdul Aziz, Fiqh Dakwah: Prinsip dan Kaidah Asasi Dakwah Islam. Solo: Intermedia, 2003.

Asmuni Syukir, Dasar-Dasar Strategi Dakwah Islam. Surabaya: Al-Ikhlas, 1983.

Alo Liliweri, Komunikasi Antar Personal. Jakarta: Prenada Media Group, 2015.

Brent D. Ruben, dkk, Komunikasi dan Perilaku Manusia Edisi Kelima. Jakarta: PT RajaGrafindo Persada, 2013.

Burhan Bungin, Sosiologi Komunikasi Teori, Paradigma, dan Diskursus Teknologi Komunikasi di Masyarakat. Jakarta: Kencana, 2006.

Burhan Bungin, Sosiologi Komunikasi: Teori, Paradigma, dan Diskursus TeknologiKomunikasi di Masyarakat. Jakarta: Kencana Prenadamedia Group, 2006.

Burhan Bungin, Metodelogi Penelitian Kuantitatif Cetakan ke II. Jakarta: Prenada Media Group, 2005. 
Cresswell, J. W. Research Design: Quantitaive And Qualitative Approach. London: Sage, 1994

Deddy Mulyana, Metodologi Penelitian Kualitatif. Bandung: PT Remaja Rosdakarya, 2003.

Deddy Mulyana, Filsafat Komunikasi. Tradisi dan Metode Fenomenologi. Bandung: PT Remaja Rosdakarya, 2013.

Dr. Mahi. M Hikmat, Metodologi Penelitian dalam Perspektiv Ilmu Komunikasi Sastra.

Yogyakarta: Graha Ilmu, 2011.

Djamaludin Ancok, Psikologi Kepemimpinan \& Inovasi. Jakarta: Erlangga, 2012.

Drs. Kustadi Suhandang, Ilmu Dakwah Perspektif Komunikasi. Bandung: PT. Remaja Rosdakarya, 2013.

Everett M. Rogers, Diffution of Innovation. London: Collier Macmillan Publisher, 1983.

Elfinaro Ardianto dan Lukiati Komala E, Komunikasi Massa Sebagai Sebuah Pengantar. Bandung: Simbiosa Rekatama Media.

Endang Saifuddin Anshari, Wawasan Islam. Jakarta: CV Rajawali, 1986.

Fathul Wahid, E-dakwah, Dakwah Melalui Internet. Yogyakarta: Gava Media, 2004.

Hami M. Hikmat, Metode Penelitian Kualitatif Pendekatan Praktis Penulisan Proposal dan

Laporan Penelitian. Malang: UMM Pers, 2010.

Hafi Anshari, Pemahaman dan Pengalaman Dakwah. Surabaya: AlIkhlas, 1993.

H.M Masyur Amin, Dakwah dan Pesan Moral. Yogyakarta: Al-Amin Press, 1997.

Ihat Solihat, "Strategi Komunikasi Persuasif Pengurus Gerakan Pemuda Hijrah dalam Berdakwah". KPI, UIN Jakarta, 2017.
Imam Gunawan, Metode Penelitian Kualitatif. Teori dan Praktik. Jakarta: PT. Bumi Aksara, 2013.

Jalaludin Rakhmat, Psikologi Komunikasi. Bandung: Remaja Rosdakarya, 1986.

Lexy, J. Meleong, Metodelogi Penelitian Kualitatif . Bandung: PT.Remaja Rosdakarya, 2007.

Moh.Ali Azis, Ilmu Dakwah Edisi Revisi. Jakarta: Kencana, 2009.

Moh. Ali Aziz, Ilmu Dakwah. Jakarta: Prenada Media Group, 2004.

Michael. Quinn Patton, Qualitative Research and Evaluation Methods, $3^{\text {rd }}$ Edition. Thousand Oaks, California: Sage Publications, 2002.

Masyhur Amin, Dakwah Islam dan Pesan Moral. Yogyakarta: Al Amin Press, 1997.

Mardikanto, Penyuluhan Pembangunan Pertanian. Solo: UNS Press, 1993.

Masyhur Amin, Dakwah Islam dan Pesan Moral. Yogyakarta: Al Amin Press, 1997.

Onong Uchjana Effendy, Ilmu Komunikasi, Teori dan Praktek. Bandung: Remaja Rosdakarya, 2005.

Pawito, Penelitian Komunikasi Kualitatif. Yogyakarta: LKIS, 2007.

Pardianto, Jurnal Komunikasi Islam Meneguhkan Dakwah melalui New Media. Fakultas Dakwah Sunan Ampel, 2013.

Rendy Ramadhon, "Pengaruh Akun Dakwah SHIFT di Instagram Terhadap Perilaku Religius Mahasiswa Ilmu Komunikasi Tahun Angkatan 2015 Universitas Islam Negeri Sunan Ampel Surabaya”. Ilmu Komunikasi, UIN Sunan Ampel Surabaya, 2019.

Rudi Hidayat, dkk, Teknologi Komunikasi dan Informasi SMA untuk Kelas XIII. Jakarta: Erlangga, 2004.

Syarifudin Yunus, Jurnalistik Terapan. Bogor: Graha Indonesia, 2010. 
Suranto Aw, Komunikasi Interpersonal. Yogyakarta: Graha Ilmu, 2010.

Sutrisno Hadi, Metodologi Research. Jakarta: Andi Offset, 1993.

Sarlito W. Sarwono, Membangun Komunikasi. Jakarta: PT. Rajagrafindo, 2009.

Saerozi, Ilmu Dakwah. Yogyakarta: Penerbit Ombak Dua, 2013.

Suparta dan Henfi, Metodologi Dakwah. Jakarta: Kencana, 2006.

Samsul Munir Amin, Ilmu Dakwah. Jakarta: Amzah, 2009.

Solis\&Breakendridge, Putting the Public Back in Public Relation: How media Social is Reinventing the Agging Business of PR. New Jersey: Pearson Education, 2009.

Tata Sukayat, Quantum Dakwah. Jakarta: Rineka Cipta, 2009.

Wardi Bachtiar, Metode Penelitian Ilmu Dakwah. Ciputat: Logos Wacana Ilmu, 1997.

Wahidin Saputra, Pengantar Ilmu Dakwah. Jakarta: Rajawali Pers, 2012.

Wahyu Ilahi, komunikasi Dakwah. Bandung: PT. Remaja Rosdakarya, 2010.

Yuniar Supardi, Internet Untuk Segala Kebutuhan. Jakarta: Salemba Infotek, 2005. 